\title{
Benzylic C-H Borylation on Ceria-Supported Nickel Hydroxides
}

Polymer-Supported

Synthesis

\section{Key words}

\section{C-H activation}

borylation

$\mathrm{NiCl}_{2} \cdot 6 \mathrm{H}_{2} \mathrm{O}+\mathrm{CeO}_{2} \quad \frac{\mathrm{pH}=10}{\mathrm{H}_{2} \mathrm{O} \text {, r.t., } 24 \mathrm{~h}} \mathrm{Ni}(\mathrm{OH})_{\mathrm{x}} / \mathrm{CeO}_{2}$

nickel catalysis

\section{Synfact $y$ Month}

\section{Selected results:}

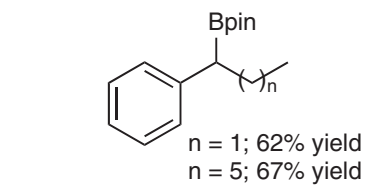<smiles>CC(C)CC(Br)c1ccccc1</smiles><smiles>c1ccc(C(c2ccccc2)c2ccccc2)cc1</smiles><smiles>CN(C)c1ccc(C(Cc2ccccc2)c2ccc(N(C)C)cc2)cc1</smiles>

$\mathrm{Ni}(\mathrm{OH})_{\times} / \mathrm{CeO}_{2}(3.6-11 \mathrm{~mol} \% \mathrm{Ni})$<smiles>Cc1ccccc1</smiles>
$\mathrm{HBpin}$ (4 equiv)

methylcyclohexane or $\mathrm{CPME}$ argon, $120^{\circ} \mathrm{C}, 4 \mathrm{~h}$<smiles></smiles><smiles>BrC(Br)c1ccccc1</smiles>

Selected results:

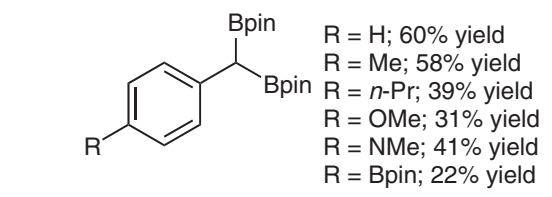

$$
\begin{aligned}
& \mathrm{R}=2-\mathrm{Me} ; 48 \% \text { yield } \\
& \mathrm{R}=3-\mathrm{Me} ; 68 \% \text { yield } \\
& \mathrm{R}=3-\mathrm{NMe} ; 57 \% \text { yield } \\
& \mathrm{R}=3-\mathrm{Bpin} ; 53 \% \text { yield }
\end{aligned}
$$<smiles>Cc1cc(C)cc(C(Cc2ccccc2)Cc2ccccc2)c1</smiles><smiles></smiles>

$\mathrm{Ni}(\mathrm{OH})_{x} / \mathrm{CeO}_{2}-\mathrm{HBpin}(1.8 \mathrm{~mol} \% \mathrm{Ni})$ $\underset{\text { neat or CPME, argon, } 120^{\circ} \mathrm{C}, 4 \mathrm{~h}}{\stackrel{\text { HBpin (0.4 equiv) }}{\longrightarrow}}$<smiles>BrCc1ccccc1</smiles>

Selected results:
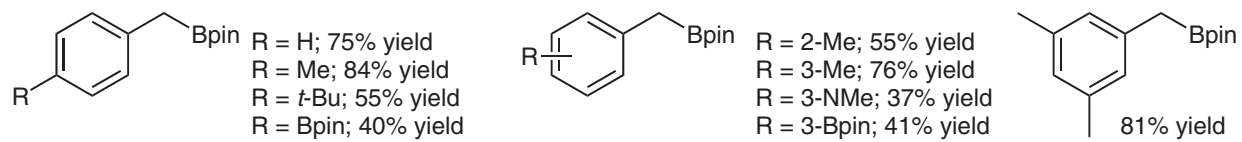

Significance: Nickel hydroxides supported on $\mathrm{CeO}_{2}\left(\mathrm{Ni}(\mathrm{OH})_{x} / \mathrm{CeO}_{2}\right)$, prepared by mixing $\mathrm{NiCl} \cdot 6 \mathrm{H}_{2} \mathrm{O}$ and $\mathrm{CeO}_{2}$ in $\mathrm{H}_{2} \mathrm{O}(\mathrm{pH}=10)$ (eq. 1), catalyzed the benzylic $\mathrm{C}-\mathrm{H}$ borylation of alkylarenes or diphenylmethanes with pinacolborane to give the corresponding benzylic boronates (eq. 2). In the reaction of methylarenes, gem-diborylated products were obtained as the main products (eq. 3 ). The monoborylation of methylarenes was also achieved by using the catalyst pretreated with HBpin and with the methylarene as the solvent (eq. 4).
Comment: $\mathrm{Ni}(\mathrm{OH})_{x} / \mathrm{CeO}_{2}$ was characterized by means of XANES XPS, EXAFS, HAADF-STEM, STEMEDS, XRD, and ICP-AES analyses. A hot-filtration experiment suggested that the reaction occurred heterogeneously. 